\title{
INFLUENCE OF INTERSPECIFIC VARIATION ON TREE CARBON STOCK OF A BRAZILIAN CERRADO ${ }^{1}$
}

Sabina Cerruto Ribeiro ${ }^{2 *}$, Laércio Antônio Gonçalves Jacovine ${ }^{3}$, Carlos Moreira Miquelino Eleto Torres ${ }^{3}$ and Agostinho Lopes Souza ${ }^{3}$

\footnotetext{
${ }^{1}$ Received on 30.09.2016 accepted for publication on 10.08.2017.

${ }^{2}$ Universidade Federal doAcre, Centro de Ciências Biológicas e da Natureza, Rio Branco, Acre-Brasil. E-mail: <sabina.ufac@gmail.com>.

${ }^{3}$ Universidade Federal de Viçosa, Departamento de Engenharia Florestal, Viçosa, Minas Gerais - Brasil. E-mail: <jacovine@ufv.br>, <carlos.eleto@ufv.br> and <alsouza@ufv.br>.

*Corresponding author.
}

\begin{abstract}
Cerrado is a biodiversity hotspot and possibly the most threatened tropical savanna in the world. Although Cerrado has an important role in the global carbon balance, studies about carbon stock in the biome are rare, especially with estimates per species. Thus, we estimated the carbon content and stock by species in a Cerrado area. We destructively sampled 120 trees from 18 species to determine tree aboveground biomass at a cerrado sensu stricto remnant. The carbon content in dry biomass was determined in laboratory and for the species not sampled an average value was used. The biomass of the remaining inventoried trees was estimated using an allometric equation. The carbon content in dry biomass had mean of $50.5 \pm 0.20 \%$ and the carbon stock for the Cerrado remnant accounted for $22,385.46 \mathrm{~kg} \mathrm{ha}^{-1}$. Results indicated that some species had higher carbon stock than others. The number of individuals, their size and wood density are key points that need to be considered in the evaluation of carbon stock in forests with large number of species. Maintaining species that contribute to higher carbon stock is essential to keep a positive carbon balance in Cerrado areas
\end{abstract}

Keywords: Species diversity; Biomass; Carbon storage.

\section{INFLUÊNCIA DA VARIAÇÃO INTERESPECÍFICA NO ESTOQUE DE CARBONO ARBÓREO DE UM CERRADO BRASILEIRO}

\begin{abstract}
RESUMO - O Cerrado é um hotspot de biodiversidade e possivelmente a savana tropical mais ameaçada do mundo. Apesar do Cerrado ter um importante papel no balanço de carbono global, estudos sobre o estoque de carbono neste bioma são raros, especialmente com a geração de estimativas por espécie. Dessa forma, neste estudo foi estimado o teor e estoque de carbono por espécie em uma área de Cerrado. Para isso, 120 árvores pertencentes a 18 espécies foram amostradas destrutivamente para se determinar a biomassa acima do solo em um fragmento de cerrado sensu stricto. O teor de carbono na biomassa seca foi determinado em laboratório e para as espécies que não foram amostradas foi usado um valor médio de teor de carbono. A biomassa das demais árvores inventariadas foi estimada usando-se uma equação alométrica. O teor de carbono médio na biomassa seca foi de 50,5 $\pm 0,20 \%$ e o estoque de carbono para o fragmento de Cerrado avaliado foi de 22.385,46 $\mathrm{kg} \mathrm{ha}^{-1}$. Os resultados indicam que algumas espécies tem um estoque de carbono maior que outras. O número de indivíduos, o tamanho e a densidade da madeira são pontos-chave que precisam ser considerados para a avaliação do estoque de carbono em florestas com grande número de espécies. A manutenção das espécies que contribuem com um alto estoque de carbono é essencial para manter um balanço de carbono positivo em áreas de Cerrado.
\end{abstract}

Palavras-Chave: Diversidade de espécies; Biomassa; Estoque de carbono.

Revista Árvore. 2017;41(5):e410506 


\section{INTRODUCTION}

Forests are large carbon reservoirs that play an important role in the context of climate change. The capacity of trees to absorb carbon dioxide from the atmosphere and store it as biomass can mitigate global $\mathrm{CO}_{2}$ emissions. However, disturbances such as fire or land use change alter forest structure and, therefore, forest carbon stock. This fact can be explained by interspecific differences in carbon storage. Considering identical biomass volumes, trees with high wood density store more carbon per unit volume than trees with lower wood density. Pioneer species tolerate a lower wood density than late-successional ones. Therefore, in a heterogeneous forest, species that occupy different ecological niches will complement each other comprising a total carbon stock that is usually higher than that of pure stands (Pretzsch, 2005; Jandl et al., 2007).

Forest carbon stock assessments are a way to detect interspecific differences in carbon storage. Based on data collected in forest inventories, the carbon stock is determined per species using direct (harvesting and weighing trees) or indirect measurements (biomass expansion factors or allometric equations). Understanding the role of each species in carbon storage is fundamental in the context of climate change, especially in managed forests. Forest management practices can balance the harvesting of species with high economic value and the maintenance of species that efficiently sequester and store carbon in biomass. This is one of the most cost-effective options to mitigate climate change (Intergovernmental Panel on Climate Change, 2007, 2014). However, because different species have distinct strategies to capture and store carbon, it is important to know which species are the major drivers of carbon storage in an area (Conti and Díaz, 2013). Studies that link tree species diversity with forest productivity (and therefore carbon stock) are more frequent in temperate and boreal forests (Caspersen and Pacala, 2001; Vilà et al., 2007; Paquette and Messier, 2011) than in highly diverse tropical forests (Cavanaugh et al., 2014). Moreover, most studies present productivity estimates by forest type and not by species. In savanna ecosystems this is also the case, as species-specific carbon stock data is scarce in the literature.

Savannas cover approximately $20 \%$ of the land area of terrestrial vegetation and are discontinuous landscapes formed by a prevailing grass layer and scattered trees (Gwenzi and Lefsky, 2014). In woodland

Revista Árvore. 2017;41(5):e410506 savannas, trees occur throughout the landscape and play an important role, as a keystone component for carbon sequestration and stocks in these ecosystems (San Jose et al., 1998; Tilman et al., 2000; Barbosa and Fearnside, 2004, 2005). Tropical savannas have a high species diversity when compared with temperate grassland and dry forests (Solbrig et al., 1996). Because 0.05 ha of tropical savanna may contain more than 30 different tree species (Ribeiro et al., 2011), including many endemic ones, it is a challenge to determine which tree species are more efficient in storing carbon as biomass. The Cerrado is a neotropical moist savanna located in central Brazil encompassing 204.7 million hectares, making it the largest savanna in South America (Silva and Bates, 2002). It is a biodiversity hotspot; however it is possibly most threatened tropical savanna in the world, with $\sim 48.5 \%$ of its original cover cleared (Silva and Bates, 2002; Myers et al., 2000; Mittermeier et al., 2005; Sano et al., 2010). Despite the importance of Cerrado in the global carbon balance (Brasil, 2010), few studies have assessed carbon stock in Cerrado areas. Most of the published studies focus on biomass quantification (an extensive review is provided by Miranda et al., 2014) and the few that are dedicated to estimating Cerrado carbon stock have assumed that $50 \%$ of tree biomass is carbon (e.g. Grace et al., 2006; Rezende et al., 2006). To our knowledge, there is no published study that has quantified carbon stock by species in a Cerrado area using carbon content in dry biomass determined in the laboratory.

In this study we use biomass field data, allometric relationships and laboratory-determined carbon content to estimate the aboveground carbon stock by species in an area of Brazilian Cerrado. We address the following questions: (1) do Cerrado species have significantly different capacities to store carbon? (2) what are the key factors that determine carbon storage in Cerrado species?.

\section{MATERIALS AND METHODS}

\subsection{Study area}

The study was conducted in a protected Cerrado remnant located in in the municipality of Curvelo, in the state of Minas Gerais, in southeast of Brazil (1848'39"S; 44³3'53"W). The 35 hectare fragment was located inside an area of Eucalyptus plantation owned by Plantar S/A, a privately owned pig-iron company. 
Red latosols underlie the study area which has an elevation of about $600 \mathrm{~m}$. The average annual temperature in Curvelo is $23^{\circ} \mathrm{C}$. The rainy season stretches from January to February, with a mean annual precipitation of $1200 \mathrm{~mm}$.

The vegetation of the study site was classified as "cerrado sensu stricto típico" (cerrado s.s. hereafter) and is characterized by high species richness of shrubs and trees with 3-6 $\mathrm{m}$ in height. The tree cover is around $20-50 \%$ (Ribeiro and Walter, 1998). The studied cerrado s.s. comprises one of many Cerrado remnants in Curvelo, where anthropic interventions have occurred mainly in the past 4-5 decades for the establishment of cashcrop agriculture and eucalyptus monocultures (Klink and Machado, 2005). As result, the region is heavily fragmented, with scattered fragments in different stages of degradation. Despite this, the study site had no clear evidence of any recent human intervention.

\subsection{Floristic and structure of the Cerrado remnant}

The data were collected in October 2009 in ten $20 \mathrm{~m} \times 25 \mathrm{~m}$ (0.05 ha) plots, systematically distributed along two transect lines. The distance between plots and between each plot and the border of the remnant was $200 \mathrm{~m}$ and $75 \mathrm{~m}$, respectively. All living trees with diameter at breast height $(\mathrm{DBH})>5 \mathrm{~cm}$ were measured for diameter and height was visually estimated by experienced field crews in $0.5 \mathrm{~m}$ classes. All measured individuals were botanically identified by specialists. The confirmation of current scientific names and author's abbreviations was performed through consultation (Jardim Botânico do Rio de Janeiro, 2014). The importance value (IV) was used as an indicator of the overall importance of each species in the community structure and was calculated as the average of the phytosociological parameters relative abundance (RA), relative frequency (RF) and relative prominence (basal area; RP; Moro and Martins, 2013).

\subsection{Quantification of biomass and carbon stock}

To estimate the carbon stock of the study site and of individual species we used previously collected samples of total above ground biomass (AGB) to estimate carbon stock; a detailed description of the methods used to collect these samples can be found in Ribeiro et al. (2011). Briefly, the aboveground biomass (bole + branches + leaves) was quantified by destructive sampling of 120 trees from 18 species. Bole, branches and leaves were separately weighed in the field and samples of each tree component were oven dried to determine dry weight. We also determined basic wood density and determined carbon content in dry biomass of individual species. Samples of bole, branches and leaves were ground in a knife mill to pass through a 100 mesh sieve. The carbon content of the re-dried regrind samples was determined using a continuousflow isotope ratio mass spectrometry (ANCA-GLS). Carbon stock per species was estimated multiplying dry weight by average carbon content per species.

The biomass of species that were not harvested was estimated using an allometric equation developed for the study area ( Ribeiro et al., 2011).

$$
\begin{aligned}
& \ln B=-3.3520+2.9853 \ln D+1.1855 \ln W D \\
& \left(\mathrm{R}^{2}=0.898 ; \mathrm{SEE}=0.371 ; \mathrm{CF}=1.071\right)
\end{aligned}
$$

where $\mathrm{B}=$ aboveground biomass in $\mathrm{kg}$; $\mathrm{D}=$ diameter at breast height in $\mathrm{cm}$ and $\mathrm{WD}=$ wood density in $\mathrm{g} \mathrm{cm}^{-3}$.

The wood density of the unharvested species was obtained in literature (Vale et al., 2002; Paula and Alves, 2007; Lorenzi, 2009; Zanne et al., 2009; Jati et al., 2014) and an average carbon content was calculated to estimate carbon stock using the mean values found for sampled species.

\section{RESULTS}

\subsection{Floristic and carbon density of the dominant species in the Cerrado remnant}

A total of 47 species were recorded, belonging to 40 genera and 29 families (Table 1). The bestrepresented families were Vochysiaceae $(42.3 \%$ individuals), Erythroxylaceae (11.4\%), Papilionoideae (5.6\%), Malpighiaceae (4.5\%), Caryocaraceae $(3.7 \%)$ and Lythraceae (2.9\%); two families were represented by only one species (Ochnaceae and Loganiaceae).

The 15 most common species accounted for approximately $78 \%$ of trees per hectare and $41 \%$ of total carbon stock in the study area. A high importance value did not necessarily mean a high carbon stock for the most common species in the remnant.

\subsection{Carbon storage}

We determined the carbon content for the 18 species harvested in the study site. There was a slight difference 
Table 1 - Carbon stock of the 15 species with highest importance values (in descending order of IV).

Tabela 1 - Estoque de carbono das 15 espécies com maior valor de importância (em ordem decrescente de VI).

\begin{tabular}{|c|c|c|c|c|}
\hline Species & IV (\%) & $\begin{array}{c}\text { Basal area } \\
\left(\mathrm{m}^{2} \mathrm{ha}^{-1}\right)\end{array}$ & $\begin{array}{c}\text { Carbon stock } \\
\left(\mathrm{kg} \mathrm{ha}^{-1}\right)\end{array}$ & $\begin{array}{c}\% \text { of the total } \\
\text { carbon stock }\end{array}$ \\
\hline Qualea parviflora Mart. & 19.86 & 4.53 & 22.87 & 2.53 \\
\hline Qualea grandiflora Mart. & 9.67 & 1.85 & 18.5 & 2.05 \\
\hline Erythroxylum suberosum A.St.-Hil. & 7.32 & 1.07 & 9.7 & 1.07 \\
\hline Caryocar brasiliense Cambess. & 5.29 & 1.42 & 154.76 & 17.12 \\
\hline Eriotheca gracilipes (K.Schum.) A.Robyns & 3.25 & 0.54 & 23.67 & 2.62 \\
\hline Lafoensia pacari A.St.-Hil. & 3.03 & 0.25 & 7.05 & 0.78 \\
\hline Byrsonima coccolobifolia Kunth & 2.82 & 0.23 & 6.34 & 0.70 \\
\hline Kielmeyera coriacea Mart. \& Zucc. & 2.68 & 0.23 & 5.32 & 0.59 \\
\hline Astronium fraxinifolium $\mathrm{Schott}$ & 2.64 & 0.21 & 8.7 & 0.96 \\
\hline Acosmium sp. & 2.63 & 0.28 & 11.86 & 1.31 \\
\hline Solanum sp. & 2.55 & 0.54 & 35.09 & 3.88 \\
\hline Tachigali sp. & 2.26 & 0.33 & 32.28 & 3.57 \\
\hline Piptocarpha rotundifolia (Less.) Baker & 2.22 & 0.15 & 5.11 & 0.57 \\
\hline Acosmium dasycarpum (Vogel) Yakovlev & 2.15 & 0.19 & 14.02 & 1.55 \\
\hline Terminalia argentea Mart. & 2.00 & 0.22 & 18.17 & 2.01 \\
\hline Other species in total ( 32 species) & 29.63 & 2.88 & 530.52 & 58.69 \\
\hline
\end{tabular}

among carbon content in dry biomass of leaves and bole+branches, but the mean carbon content of both tree compartments was similar (Table 2).

The tree carbon stock for the Cerrado study site was estimated to be $22,385.5 \mathrm{~kg} \mathrm{ha}^{-1}(\mathrm{SE} \%=35.4 \%)$. The distribution of trees by $5 \mathrm{~cm}$ diameter classes revealed that $57.0 \%$ of carbon storage occurred in trees $40-45$ $\mathrm{cm} \mathrm{DBH}$, while $25.5 \%$ and $17.5 \%$ was stored in trees 30-35 cm DBH and 25-30 cm DBH, respectively. There were no trees in 35-40 cm diameter class. However, when the number of trees per ha in each diameter class is contrasted with the average carbon storage, we realize the role of larger trees in determining the carbon storage in the area is very important (Figure 1).

\subsection{Average carbon stock per species}

We found that Cerrado species have different capacities to store carbon and this varies according to the number of individuals, their size and wood density. For example, Caryocar brasiliense had the highest relative contribution to carbon stock, while also having a high number of individuals per hectare (Figure 2). Further, only this species had individuals larger than $30 \mathrm{~cm} \mathrm{DBH}$. It had wood density of $0.61 \mathrm{~g} \mathrm{~cm}^{-3}$ and accounted for more than $80 \%$ of the carbon storage in the area.

Qualea grandiflora (262 trees ha-1) and Qualea parviflora $\left(526\right.$ trees $\left.\mathrm{ha}^{-1}\right)$ are examples of species with high number of trees per hectare, medium wood density and a low carbon stock. Together they accounted for almost $40 \%$ of all inventoried trees (Q. grandiflora $-12.6 \%$ and $Q$. parviflora $-25.2 \%$ ). Nonetheless, their carbon stock $\left(<23 \mathrm{~kg} \mathrm{ha}^{-1}\right)$ was among the lowest of the top ranked carbon storing species. On a smaller scale, this trend is also noticed for Solanum sp., Tachigali sp. and Eriotheca gracilipes.

Pouteria ramiflora and Curatella americana showed a great potential for carbon storage. Despite having low numbers of individuals $(<9$ trees ha-1), these species hold the second and third largest carbon stock in the area ( $P$. ramiflora $-82.5 \mathrm{~kg} \mathrm{ha}^{-1}$ and $C$. americana $\left.-48.5 \mathrm{~kg} \mathrm{ha}^{-1}\right)$. P. ramiflora had trees equally distributed in small and medium size diameter classes (5-20 cm DBH), while $75 \%$ of $C$. americana trees were between 20 and $30 \mathrm{~cm} \mathrm{DBH}$. The wood density was $0.70 \mathrm{~g} \mathrm{~cm}^{-3}$ for $P$. ramiflora and $0.51 \mathrm{~g} \mathrm{~cm}^{-3}$ for $C$. americana. Other species presented carbon stocks relatively consistent with their abundance.

\section{DISCUSSION}

\subsection{Carbon storage in the Cerrado remnant}

The carbon content in dry biomass of 18 species of cerrado sensu stricto that are among the most common and widespread woody species for the Cerrado region was determined to be between $47.7 \%$ and $54.6 \%$ (Ratter et al., 2003; Table 2). Kauffman et al. (1994), Barbosa

Revista Árvore. 2017;41(5):e410506 
Table 2 - Mean carbon content in dry biomass of leaves and bole+branches by species (only harvested species). Tabela 2 - Teor de carbono médio na biomassa seca de folhas e tronco+galhos por espécie (apenas espécies abatidas).

\begin{tabular}{lcc}
\hline Species & & Carbon content (\%) \\
\cline { 2 - 3 } & Leaves & Wood \\
\hline Acosmium sp. & 49.0 & 50.2 \\
Astronium fraxinifolium Schott & 51.6 & 48.8 \\
Byrsonima coccolobifolia Kunth & 48.9 & 52.2 \\
Curatella americana L. & 47.7 & 49.2 \\
Eriotheca gracilipes K. Schum.) A.Robyns & 49.2 & 47.9 \\
Erythroxylum suberosum A.St.-Hil. & 49.5 & 50.3 \\
Lafoensia pacari A.St.-Hil. & 50.2 & 51.9 \\
Piptocarpha rotundifolia (Less.) Baker & 53.1 & 52.8 \\
Plathymenia reticulata Benth. & 50.5 & 47.9 \\
Pouteria torta (Mart.) Radlk. & 52.7 & 50.7 \\
Pterodon emarginatus Vogel & 54.6 & 51.8 \\
Qualea grandiflora Mart. & 48.9 & 50.5 \\
Qualea parviflora Mart. & 48.1 & 49.3 \\
Tachigali sp. & 53.2 & 51.1 \\
Solanum sp. & 51.5 & 51.8 \\
Strychnos pseudoquina A.St.-Hil. & 47.8 & 51.0 \\
Stryphnodendron adstringens (Mart.) Coville & 54.3 & 53.3 \\
Terminalia argentea Mart. & 50.6 & 47.7 \\
\hline Mean \pm CI ${ }^{1}$ & $50.6 \pm 0.26$ & $50.5 \pm 0.20$ \\
\hline
\end{tabular}

${ }^{1}$ Confidence interval

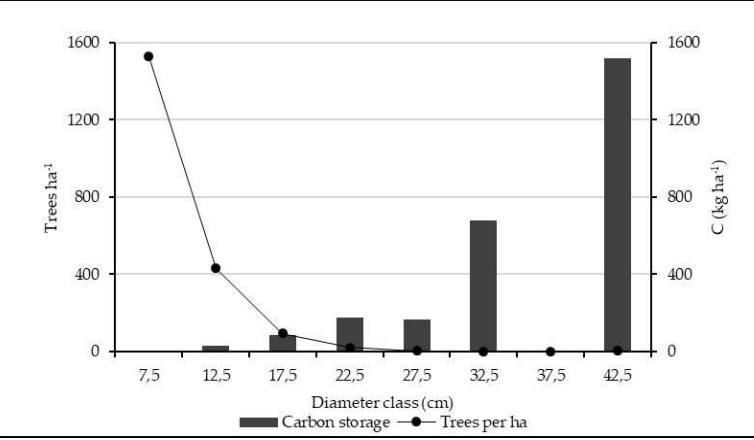

Figure 1 - Average carbon storage and number of trees in a Cerrado remnant in Minas Gerais, Brazil.

Figura 1 - Estoque de carbono médio e número de árvores em um remanescente de Cerrado em Minas Gerais, Brasil.

and Fearnside (2005) and Scolforo et al. (2008) found a carbon content for cerrado s.s areas ranging from $46.1 \%$ to $52 \%$, values that are comparable to the ones we found (47.7-54.6\% - leaves; 47.7-50.5\% - wood; Table 2). Nevertheless, none these studies showed species-specific carbon content values, but only an average value for the physiognomy.

We calculated the carbon stock for all the species registered in a Cerrado remnant and found that 15 species accounted for $\sim 41 \%$ of total carbon stock in the study area. This means that the remaining 32 species $(59 \%$ of total carbon stock) had only a small amount of influence on the carbon stock of the Cerrado remnant, indicating the key role these 15 species play as primary contributors to carbon stock in the area. Similarly, the study by Lung and Espira (2015) pointed out that a select group of 10 species was the major contributors to aboveground biomass, hence affecting the local carbon stock variability. We also noticed that species with higher carbon stock did not necessarily have a high importance value (Table 1 and Figure 2 a), i.e. a broad distribution and large size did not solely explain the influence of a species on the carbon stock of the Cerrado remnant.

With respect to size, the distribution of carbon stock in diameter size classes emphasized the importance of larger trees in composing the remnant's carbon stock. Despite trees with $\mathrm{DBH}>40 \mathrm{~cm}$ representing only $0.2 \%$ of trees in the study area, they were responsible for more than half of carbon stock estimated in the study site. The influence of large trees in the forest biomass (and therefore carbon) is also reported in other studies (e.g. Kirby and Potvin, 2007; Slik et al., 2013; Sist et al., 2014). 

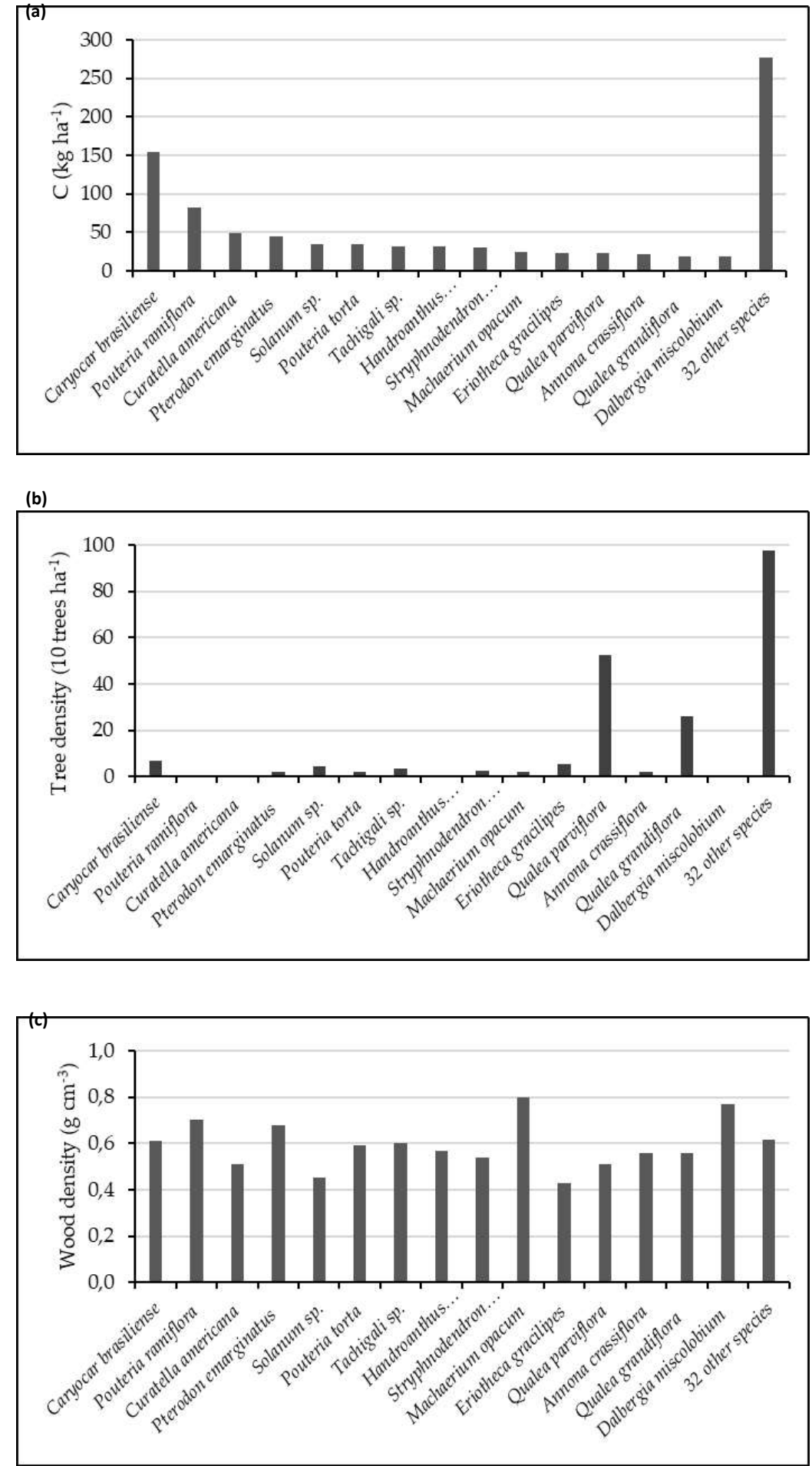

Figure 2 - Carbon stock (a), tree density (b) and wood density (c) of 15 top ranked carbon storing species.

Figura 2 - Estoque de carbono (a), densidade de árvores (b) e densidade da madeira c) das 15 espécies com maior estoque de carbono.

Revista Árvore. 2017;41(5):e410506 


\subsection{Average carbon stock per species}

We found that some species are able to more efficiently stock carbon than others, which strengthens the need for determination of carbon content in dry biomass per species in laboratory. The number of individuals, their size and wood density are key factors that determine carbon storage in the species sampled. For instance, Caryocar brasiliense had the highest carbon stock among all the species sampled. The presence of some large individuals $(\mathrm{DBH}>30 \mathrm{~cm})$ was a major factor contributing to the high carbon stock of this species, as the large trees accounted for $16.6 \%$ of total carbon stock in the area. Baker et al. (2004), Slik et al. (2010) and Cavanaugh et al. (2014) also found a positive relationship between higher diameters and aboveground carbon stock in tropical forests. Moreover, C. brasiliense wood density $\left(0.61 \mathrm{~g} \mathrm{~cm}^{-3}\right)$ is above average for the study area $\left(0.57 \mathrm{~g} \mathrm{~cm}^{-3}\right)$. This species is widely distributed in Cerrado areas and can have densities of up to 180 trees per hectare (Brandão and Gavilanes, 1992; Almeida et al., 1998).

Qualea grandiflora and Qualea parviflora also have a broad distribution in Cerrado vegetation (Ratter et al., 2003). However, in the study area most of individuals from these species were small (almost $90 \%$ had DBH $<15 \mathrm{~cm}$ ) and had a medium wood density ( $Q$. grandiflora $-0.56 \mathrm{~g} \mathrm{~cm}^{-3}$ and $Q$. parviflora $\left.-0.51 \mathrm{~g} \mathrm{~cm}^{-3}\right)$, which led to lower carbon stock totals for both species.

Pouteria ramiflora and Curatella americana presented a high carbon stock despite having a low number of individuals (Table 1). In the case of both species, the presence of large trees is not solely enough to explain the carbon stock differences. Tree carbon stock may vary with site conditions (e.g. climate, soil) and species features, like growth pattern and wood density. For example, Pouteria ramiflora and Curatella americana have wood densities of 0.70 and $0.51 \mathrm{~g} \mathrm{~cm}^{-}$ ${ }^{3}$, respectively (Ribeiro et al., 2011). Therefore, in the case of Pouteria ramiflora, the high wood density plays a major role in defining carbon stock. Curatella americana has a wood density similar to Qualea grandiflora $\left(0.56 \mathrm{~g} \mathrm{~cm}^{-3}\right)$ and Q. parviflora $\left(0.51 \mathrm{~g} \mathrm{~cm}^{-}\right.$ 3; Ribeiro et al., 2011), however higher diameter sizes compensated for lower numbers of these species.

Key factors that determined carbon storage in the species sampled included number of individuals, their size and wood density, nonetheless it is important to consider forest age. Aboveground biomass and carbon stock are largely affected by tree age (Pregitzer and Euskirchen, 2004; Wei et al., 2013), which indicates the growing stage of a species and its potential to sequester and stock carbon in biomass (Dube and Mutanga, 2015). This means that if one species has a higher carbon stock than another, it may be that this species is older. We do not have any reliable information about the species age of the studied Cerrado remnant however, which hampers any attempt to make inferences regarding this issue. In the literature, studies that correlate biomass or carbon stock with age in Cerrado areas are also scarce, which calls for the development of further studies to fill this knowledge gap.

Considering our case study, we believe that the logging of some species will affect the carbon stock of the area. The selective logging of Caryocar brasiliense, for example, would deplete the carbon stock in the landscape. Fortunately, Brazilian legislation protects this species from unlawful harvest (Instituto Brasileiro do Meio Ambiente e dos Recursos Naturais Renováveis, 1996). However, species like Pouteria ramiflora and Curatella americana are less protected. The logging of these species would have a negative impact in the carbon balance of an area. Therefore, maintaining species that stock carbon more efficiently is essential to keep a positive carbon balance in Cerrado areas.

Nonetheless, more than $48 \%$ of Cerrado original cover has already been cleared for the establishment of agricultural and cattle ranching activities (Brannstrom et al., 2008; Brasil, 2011). In addition to illegal harvesting, climate change is also a threat to the Cerrado biome as elevated temperatures may lead to increased fire events reducing biomass and nutrients stock, in addition to diversity loss (Painel Brasileiro de Mudanças Climáticas, 2013). The growing emphasis on adaptation to climate change and the provision of ecosystem services highlight the need to shift Cerrado land use patterns before it is too late.

\section{CONCLUSIONS}

In this study, we investigated whether Cerrado species have different capacities to store carbon and which are the factors that determine carbon storage in those species. Our results have showed that 15 species play as primary contributors to carbon stock in the study area, indicating that some species are able to more efficiently stock carbon than others. The capacity 
of each species to stock carbon will depend on the number of individuals, their size and wood density. Therefore, harvesting species that stock carbon efficiently may negatively affect the carbon balance of Cerrado areas.

\section{ACKNOWLEDGMENTS}

We are most of grateful for the critical reading of previous versions of the manuscript provided by S. Perz, F. Brown and E. Bruna at publishing paper workshop supported by the project "Strengthening alliance between university and other research organization to build capacity for applied environmental research in the Andes-Amazon Rim" from Higher Education for development and US Agency for International Development. We gratefully acknowledge financial support for this study from FAPEMIG (Grant No. CAG2327-07) and CNPq (productivity grants). We also thank C. Staudhammer for comments that improved this manuscript.

\section{REFERENCES}

Almeida SP, Proença CEB, Sano SM, Ribeiro JF. Cerrado: espécies vegetais úteis. Planaltina: EMBRAPA; 1998. 464 p.

Baker TR, Phillips OL, Malhi Y, Almeida S, Arroyo L, Di Fiore A, et al. Variation in wood density determines spatial patterns in Amazonian forest biomass. Glob Change Biol. 2004;10(5):545-62. http://dx.doi.org/10.1111/j.1365-2486.2004.00751.x.

Barbosa RI, Fearnside PM. Above-ground biomass and the fate of carbon after burning in the savannas of Roraima, Brazilian Amazonia. For Ecol Manage. 2005;216(1-3):295-316. http:// dx.doi.org/10.1016/j.foreco.2005.05.042.

Barbosa RI, Fearnside PM. Wood density of trees in open savannas of the Brazilian Amazon. For Ecol Manage. 2004;199(1):115-23. http://dx.doi.org/ 10.1016/j.foreco.2004.05.035.

Brandão M, Gavilanes ML. Espécies arbóreas padronizadoras do cerrado mineiro e sua distribuição no estado. Inf. Agropecu. 1992;16(173):5-11.

Brannstrom C, Jepson W, Filippi AM, Redo D, Xu $\mathrm{Z}$, Ganesh S. Land change in the Brazilian
Savanna (Cerrado), 1986-2002: comparative analysis and implications for land-use policy. Land Use Policy. 2008;25(4):579-95. http:// dx.doi.org/10.1016/j.landusepol.2007.11.008.

Brasil. Ministério do Meio Ambiente. Plano de ação para prevenção e controle do desmatamento e das queimadas no Cerrado - PPCerrado. Brasília: MMA; 2010. 200 p.

Brasil. Ministério do Meio Ambiente. Relatório técnico de monitoramento do desmatamento no bioma Cerrado, 2009 a 2010. Brasília: MMA; 2011 [cited 2016 Aug 04]. Available from: http:// www.mma.gov.br/estruturas/sbf_chm_rbbio/ _arquivos/relatoriofinal_cerrado_2010_ final_72_1.pdf

Caspersen JP, Pacala SW. Successional diversity and forest ecosystem function. Ecol Res. 2001;16(5):895-903. http://dx.doi.org/10.1046/j.14401703.2001.00455.x.

Cavanaugh KC, Gosnell JS, Davis SL, Ahumada J, Boundja P, Clark DB, et al. Carbon storage in tropical forests correlates with taxonomic diversity and functional dominance on a global scale. Glob Ecol Biogeogr. 2014;23(5):563-73. http://dx.doi.org/10.1111/geb.12143.

Conti G, Díaz S. Plant functional diversity and carbon storage: an empirical test in semi-arid forest ecosystem. J Ecol. 2013;101(1):18-28. http:// dx.doi.org/10.1111/1365-2745.12012.

Dube T, Mutanga O. Quantifying the variability and allocation patterns of aboveground carbon stocks across plantation forest types, structural attributes and age in sub-tropical coastal region of KwaZulu Natal, South Africa using remote sensing. Appl Geogr. 2015;64:5565. http://dx.doi.org/10.1016/ j.apgeog.2015.09.003.

Grace J, Jose JS, Meir P, Miranda HS, Montes RA. Productivity and carbon fluxes of tropical savannas. J Biogeogr. 2006;33(3):387-400. http:// dx.doi.org/10.1111/j.1365-2699.2005.01448.x.

Gwenzi D, Lefsky MA. Modeling canopy height in a savanna ecosystem using spaceborne lidar waveforms. Remote Sens Environ. 2014;154:33844. http://dx.doi.org/10.1016/j.rse.2013.11.024.

Revista Árvore. 2017;41(5):e410506 
Instituto Brasileiro do Meio Ambiente e dos Recursos Naturais Renováveis. Portaria n ${ }^{\circ} 113$, de 29 dezembro de 1995. Diário Oficial da União, Brasília, 9 de janeiro de 1996. p. 323. Seção I, parte 1, no. 6 [cited 2015 Nov 10]. Available from: http://portal.in.gov.br

Intergovernmental Panel on Climate Change. Climate change 2007: mitigation of climate change. In: Metz B, Davidson OR, Bosch PR, Dave R, Meyer LA, editors. Contribution of Working Group III to the Fourth Assessment Report of the IPCC. Cambridge: IPCC; 2007. 851 p.

Intergovernmental Panel on Climate Change. Summary for policymakers. Climate Change 2014: mitigation of Climate change. In: Edenhofer O, Pichs-Madruga R, Sokona Y, Farahani E, Kadner S, Seyboth K, et al., editors. Contribution of Working Group III to the Fifth Assessment Report of the Intergovernmental Panel on Climate Change. Cambridge: IPCC; 2014. 1435 p.

Jandl R, Lindner M, Vesterdal L, Bauwens B, Baritz R, Hagedorn F, et al. How strongly can forest management influence soil carbon sequestration? Geoderma. 2007;137(3-4):253-68. http://dx.doi.org/10.1016/j.geoderma.2006.09.003.

Jardim Botânico do Rio de Janeiro. Lista de espécies da flora do Brasil. Rio de Janeiro: JBRJ; 2014 [cited 2016 Aug 04]. Available from: http:// floradobrasil.jbrj.gov.br

Jati SR, Fearnside PM, Barbosa RI. Densidade da madeira de árvores em savanas do norte da Amazônia brasileira. Acta Amazon. 2014;44(1):7986. http://dx.doi.org/10.1590/S004459672014000100008.

Kauffman JB, Cummings DL, Ward DE. Relationships of fire, biomass and nutrient dynamics along a vegetation gradient in the Brazilian Cerrado. J Ecol. 1994;82(3):519-31. http:// dx.doi.org/10.2307/2261261.

Kirby KR, Potvin C. Variation in carbon storage among tree species: implications for the management of a small-scale carbon sink project. For Ecol Manage. 2007;246(2-3):208-21. http:// dx.doi.org/10.1016/j.foreco.2007.03.072.

Klink CA, Machado RB. Conservation of the Brazilian Cerrado. Conserv Biol. 2005;19(3):707-
13. http://dx.doi.org/10.1111/j.15231739.2005.00702.x.

Lorenzi H. Árvores brasileiras. Nova Odessa: Instituto Plantarum; 2009. 384 p.

Lung M, Espira A. The influence of stand variables and human use on biomass and carbon stocks of a transitional African forest: Implications for forest carbon projects. For Ecol Manage. 2015;351:36-46. http://dx.doi.org/10.1016/ j.foreco.2015.04.032.

Miranda SC, Bustamante M, Palace M, Hagen S, Keller M, Ferreira LG. Regional variations in biomass distribution in Brazilian savanna woodland. Biotropica. 2014;46(2):125-38. http:// dx.doi.org/10.1111/btp. 12095 .

Mittermeier RA, Gil PR, Hoffman M, Pilgrim J, Brooks T, Mittermeier CG, et al. Hotspots revisited: earth's biologically richest and most endangered terrestrial ecoregions. Arlington: Conservation International; 2005. 392 p.

Moro MF, Martins FR. Métodos de levantamento do componente arbóreo-arbustivo. In: Felfilli JM, Eisenlohr PV, Melo MMRF, Andrade LA, Meira JAA No,editors. Fitossociologia no Brasil: métodos e estudos de casos. Viçosa: Editora UFV.; 2013. p. 174-212. vol. 1.

Myers N, Mittermeier RA, Mittermeier CG, Fonseca GAB, Kent J. Biodiversity hotspots for conservation priorities. Nature. 2000;403(6772):853-8. http://dx.doi.org/10.1038/ 35002501 . PMid:10706275.

Painel Brasileiro de Mudanças Climáticas. Contribuição do Grupo de Trabalho 1 ao Primeiro Relatório de Avaliação Nacional do Painel Brasileiro de Mudanças Climáticas (Sumário Executivo GT1). Rio de Janeiro: PBMC; 2013. 23 p.

Paquette A, Messier C. The effect of biodiversity on tree productivity: from temperate to boreal forests. Glob Ecol Biogeogr. 2011;20(1):170-80. http://dx.doi.org/10.1111/j.1466-8238.2010.00592.x.

Paula JE, Alves JLH. 897 madeiras nativas do Brasil: anatomia, dendrologia, dendrometria, produção, uso. Porto Alegre: Cinco Continentes; $2007.438 \mathrm{p}$. 
Pregitzer KS, Euskirchen ES. Carbon cycling and storage in world forests: biome patterns related to forest age. Glob Change Biol. 2004;10(12):2052-77. http://dx.doi.org/10.1111/j.1365-2486.2004.00866.x.

Pretzsch H. Diversity and productivity in forests: evidence from long term experimental plots. In: Scherer-Lorenzen M, Körner C, Schulze E, editors. Forest diversity and function: temperate and boreal systems. Berlin: Springer; 2005. p. 41-64. vol. 176. http://dx.doi.org/10.1007/3-540-26599-6_3.

Ratter JA, Bridgewater S, Ribeiro JF. Analysis of the floristic composition of the Brazilian Cerrado vegetation III: comparison of the woody vegetation of 376 areas. Edinb J Bot. 2003;60(1):57-109. http://dx.doi.org/10.1017/ S0960428603000064.

Rezende AV, Vale AT, Sanquetta CR, Figueiredo Filho A, Felfili JM. Comparação de modelos matemáticos para estimativa do volume, biomassa e estoque de carbono da vegetação lenhosa de um cerrado sensu stricto em Brasília, DF. Sci For. 2006;71:65-76.

Ribeiro JF, Walter BM. Fitofisionomias do bioma Cerrado. In: Sano SM, Almeida SP, editors. Cerrado: ambiente e flora. 1st ed. Planaltina: EMBRAPA; 1998. p. 89-166.

Ribeiro SC, Fehrmann L, Soares CPB, Jacovine LAG, Kleinn C, Gaspar RO. Above- and belowground biomass in a Brazilian Cerrado. For Ecol Manage. 2011;262(3):491-9. http://dx.doi.org/ 10.1016/j.foreco.2011.04.017.

San Jose JJ, Montes RA, Fariñas MR. Carbon stocks and fluxes in a temporal scaling from a savanna to a semi-deciduous forest. For Ecol Manage. 1998;105(1-3):251-62. http://dx.doi.org/ 10.1016/S0378-1127(97)00288-0.

Sano EE, Rosa R, Brito JLS, Ferreira LG. Land cover mapping of the tropical savanna region in Brazil. Environ Monit Assess. 2010;166(1-4):11324. http://dx.doi.org/10.1007/s10661-009-0988-4. PMid:19504057.

Scolforo JR, Oliveira AD, Acerbi FW Jr. Inventário florestal de Minas Gerais: equações de volume, peso de matéria seca e carbono para diferentes fitofisionomias da flora nativa. Lavras: UFLA; 2008. 216 p.
Silva JMC, Bates JM. Conservation in the South American Cerrado: a tropical savanna hotspot. Bioscience. 2002;52(3):225-33. http://dx.doi.org/ 10.1641/00063568(2002)052[0225:BPACIT]2.0.CO;2.

Sist P, Mazzei L, Blanc L, Rutishauser E. Large trees as key elements of carbon storage and dynamics after selective logging in the Eastern Amazon. For Ecol Manage. 2014;318:103-9. http:// dx.doi.org/10.1016/j.foreco.2014.01.005.

Slik JWF, Aiba SI, Brearley FQ, Cannon CH, Forshed O, Kitayama K, et al. Environmental correlates of tree biomass, basal area, wood specific gravity and stem density gradients in Borneo's tropical forests. Glob Ecol Biogeogr. 2010;19(1):50-60. http://dx.doi.org/10.1111/j.14668238.2009.00489.x.

Slik JWF, Paoli G, Mcguire K, Amaral I, Barroso J, Bastian M, et al. Large trees drive forest aboveground biomass variation in moist lowland forests across the tropics. Glob Ecol Biogeogr. 2013;22(12):1261-71. http://dx.doi.org/10.1111/ geb. 12092 .

Solbrig OT, Medina E, Silva JF. Biodiversity and tropical savanna properties: a global view. In: Mooney HA, Cushman JH, Medina E, Sala OE, Schulze ED, editors. Functional roles of biodiversity: a global perspective. New York: John Wiley \& Sons; 1996. p. 185-211.

Tilman D, Reich P, Phillips H, Menton M, Patel A, Vos E, et al. Fire suppression and ecosystem carbon storage. Ecology. 2000;81(10):2680-5. http:/ /dx.doi.org/10.1890/0012-

9658(2000)081[2680:FSAECS]2.0.CO;2.

Vale AT, Brasil MAM, Leão AL. Quantificação e caracterização energética da madeira e casca de espécies do Cerrado. Cienc Florest. 2002;12(1):7180. http://dx.doi.org/10.5902/198050981702.

Vilà M, Vayreda J, Comas L, Ibáñez JJ, Mata T, Obón B. Species richness and wood production: a positive association in Mediterranean forests. Ecol Lett. 2007;10(3):241-50. http://dx.doi.org/10.1111/ j.1461-0248.2007.01016.x. PMid:17305807.

Wei Y, Li M, Chen H, Lewis BJ, Yu D, Zhou L, et

Revista Árvore. 2017;41(5):e410506

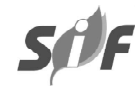


al. Variation in carbon storage and its distribution by stand age and forest type in boreal and temperate forests in Northeastern China. PLoS One. 2013;8(8):e72201. http://dx.doi.org/10.1371/ journal.pone.0072201. PMid:23977252.
Zanne AE, Lopez-Gonzalez G, Coomes DA, Ilic J, Jansen S, Lewis SL, et al. Global wood density database. Durham: Dryad; 2009 [cited 2016 Aug 20]. Available from: http://datadryad.org/resource/ doi: $10.5061 /$ dryad.234 